even more difficult task than the actual proof of economic loss. An attempt objectively to measure the emotional harm, examining such factors as the age of the child, the number of surviving children in the family, religious outlooks, and the varying values placed on family-child bonds by different strata of society would constitute an equally impossible task.

An arbitrary but substantial measure of damages would be perhaps the best solution. Such an award might be a fixed amount or a scale within which the jury could fix damages. At the same time it would be wise to continue the recognition of actual economic harm. This could be done by a statutory provision requiring specific proof of economic loss. In a relatively small percentage of cases some economic harm is undoubtedly involved and could be proved. Children killed near the end of minority are often established in jobs and have given clear indications of contributions to the family. Moreover, in exceptional cases, such as a young child employed in the amusement world, indications of contributions and income are established at a relatively early age and are capable of proof.

The suggested solution would compensate for whatever harm has occurred. Where economic and emotional harms exist together, both would be utilized in computing damages. Where, perhaps in the majority of cases, only emotional harm exists, recovery would be allowed for it alone. Such a solution would honestly deal with the actual harm involved, without straining the pecuniary-loss doctrine to fit situations where no pecuniary loss has occurred. Broader societal effects of the recognition of emotional harm would be minimized because the recovery, although substantial, would have an arbitrary ceiling. The aphorism that it is cheaper to kill a child than to kill an adult would retain its paradoxical sting of truth, yet the candid recognition of real emotional harm in the child death situation by an award of substantial, though limited, damages would constitute a more civilized solution to a perplexing damage problem.

\title{
INTERPLAY BETWEEN STATE DIRECT ACTION STATUTE AND FEDERAL ADMIRALTY LAW: ANOTHER SOLUTION TO THE CUSHING CASE
}

Marine insurance is subject to the legislative control of both the federal government and the state where the contract is written. ${ }^{1}$ While the subject matter of the contract-the liability of an owner of a vessel-falls within

\footnotetext{
${ }^{1}$ Insurance Co. v. Dunham, 11 Wall. (U.S.) 1 (1870), established the jurisdiction of a federal court sitting in admiralty over recovery on a policy of ocean marine insurance. The case contains a discussion of the origins of ocean marine insurance and admiralty proceedings. Concerning a state's legislative powers over marine insurance see Hooper v. California, 155 U.S. 648 (1894).
} 
the sphere of federal admiralty law, many aspects of the insurance contract are controlled by state law. A novel ramification of the problems raised by such overlapping federal-state control is presented by the recent case of Maryland Casualty Co. v. Cushing. ${ }^{2}$ The towboat Jane Smith capsized when it collided with a concrete pier of a railroad bridge over the Atchafalaya River in Louisiana; as a result of the accident, five seamen drowned. The owner had purchased a marine protection and indemnity insurance policy in the amount of $\$ 170,000^{3}$ which contained the following clause: "Liability of the insurer shall never exceed that of the shipowner in the absence of Contract." The insured owner of the vessel and all the victims of the accident except one were residents of Louisiana, and the insurance policy had been issued and delivered in Louisiana.

The owner brought limitation proceedings ${ }^{4}$ in admiralty to determine the extent of his liability. Should the shipowner be entitled to limitation under federal law, his liability would be limited to the value of the ship after the collision plus freight pending; ${ }^{5}$ it was estimated that the value of the Jane Smith in her then condition was $\$ 25,000 .^{6}$ The limitation proceedings

${ }^{2} 347$ U.S. 409 (1954).

${ }^{3}$ In the Cushing case a second policy in which a charterer of the vessel was named as the insured was also in suit. Much of the ensuing discussion applies to charterers as well as to owners of vessels. For purposes of simplicity reference will be made only to owners.

There are two types of ocean marine insurance: (1) hull insurance, which protects the shipowner against damage to his vessel (in addition, the usual hull policy covers damage to another ship caused by the insured ship); (2) protection and indemnity insurance, which protects the shipowner from liabilities arising principally from personal injuries, cargo damage and damage to bridges and structures on land. Consult Libby, Some Aspects of Protection and Indemnity Insurance, [1952] Ins. L.J. 684.

Ocean marine insurance differs from most other forms of insurance in that the rates are not subject to regulation by any governmental authority. Competition among insurers keeps rates low; the profit margins are said to be less than those in some other lines of insurance. Premiums are not determined by reference to actuarial tables, but are set individually by the loss experience of each risk which an underwriter accepts. The rating of a marine risk, because of its complexity, is done by one with long experience in a particular type of traffic, i.e., river, Great Lakes, coastal waters, ocean.

'In conformance with Admiralty Rules 51-55, 28 U.S.C.A. (1950), these proceedings were brought in the United States District Court, Eastern District of Louisiana.

${ }^{3}$ Freight pending is the consideration for transportation of cargo. Thus, in most instances when the cargo is destroyed the shipowner loses the freight, and this amount is not available for the payment of claims. Hereafter, in the interest of simplicity, freight pending will be omitted from any statement of the shipowner's liability.

- That the liability of the owner is limited to the value of the vessel after, and not before, the accident is not explicit in the Limitation of Liability Act: "(a) The liability of the owner of any vessel ... for any loss, damage, or injury by collision, or for any act, matter, or thing, loss, damage, or forfeiture, done, occasioned, or incurred, without the privity or knowledge of such owner or owners, shall not, except in the cases provided for in subsection (b) of this section, exceed the amount or value of the interest of such owner in such vessel, and her freight then pending." 9 Stat. 635 (1851), as amended 
were pending when representatives of the five victims brought suit under the Jones Act ${ }^{7}$ against the insurance companies in the same federal district court. ${ }^{8}$ They relied on a Louisiana statute, enacted primarily for the benefit of auto accident victims, ${ }^{9}$ which allows an injured plaintiff or his heirs to bring an action directly against the insurer before the claim has been reduced to a judgment against the insured. ${ }^{10}$ In this action the plaintiffs were attempting to reach the total proceeds of the policy. The question raised was whether the insurer could be held liable for the full amount of the policy, thus increasing its liability beyond that of the insured and exhausting funds otherwise available for the indemnification of the owner. The propositions that form the controversy are: (1) the insurer's liability cannot exceed the face amount of the policy; (2) the insurer's liability by the terms of the policy cannot exceed the liability of the insured; (3) the insured's liability can never exceed the value of the vessel after the accident, if he is entitled to limitation; and (4) the plaintiff, under the Louisiana direct action statute, can bring an action directly against the insurer before judgment is entered against the insured. The basic inquiry is whether a state is able, without contravening the federal policy of limitation of liability, to increase the insurer's obligation under a marine liability insurance policy beyond the owner's liability as determined by federal law.

46 U.S.C.A. $\$ 183$ (Supp., 1953). See note 5 supra. At the time the Court considered the case the value of the Jane Smith had not been finally determined. The estimated value of $\$ 25,000$ was used by the Court in considering the case, and will be used here as an estimate of the actual value. 347 U.S. $409,418,433-34$. The condition of a vessel after an accident is commonly referred to as its "then condition."

${ }^{7} 41$ Stat. 1007 (1920), 46 U.S.C.A. $\$ 688$ (1944). The Act gives to seamen rights against an employer similar to those given interstate railroad workers by the Employers' Liability Act, 35 Stat. 65 (1908), 45 U.S.C.A. $\$ 51$ (1954). For a discussion of the Jones Act and of other remedies of injured seamen see The Tangled Seine: A Survey of Maritime Personal Injury Remedies, 57 Yale L.J. 243 (1947). In re East River Towing Co., 266 U.S. 355 (1924), established that the Jones Act did not alter the owner's right to petition for limitation of liability.

${ }^{8}$ United States District Court, Eastern District of Louisiana.

${ }^{9}$ That this statute has involved automobile liability insurance in the great majority of cases is suggested by cases noted in the annotation, $15 \mathrm{La}$. Stat. Ann. (West, 1951) $\$ 22: 655$, at $567-92$.

${ }^{10} 15$ La. Stat. Ann. (West, 1951) $\$ 22: 655$ reads in part as follows: "No policy or contract of liability insurance shall be issued or delivered in this state, unless it contains provisions to the effect that the insolvency or bankruptcy of the insured, shall not release the insurer from the payment of damages for injuries sustained or loss occasioned during the existence of the policy ... and an action may . . . be maintained within the terms and limits of the policy by the injured person or his or her heirs . . . against the insurer alone or against both the insured and the insurer, jointly and in solido. This right of direct action shall exist whether the policy of insurance sued upon was written or delivered in the State of Louisiana or not and whether or not such policy contains a provision forbidding such direct action, provided the accident or injury occurred within the State of Louisiana." 
The district court dismissed the complaint on the grounds that the Louisiana direct action statute was worded so as to exclude marine liability insurance, and that Louisiana was without power to enlarge the remedies of injured seamen in such manner. ${ }^{11}$ The court of appeals reversed, holding that the suits might be maintained since the Louisiana statute neither disturbed the uniformity of federal maritime law nor defeated the purpose of the Limitation of Liability Act. ${ }^{12}$ On appeal, the Supreme Court vacated the judgment below and remanded the case to the district court, to be continued until after completion of the limitation proceedings. This disposition of the case, advocated in a separate opinion by Justice Clark, was adopted by compromise as the Court's decision. Four justices, in an opinion by Justice Frankfurter, favored affirming the position of the district court that suits directly against the insurers could never be maintained, yet joined Justice Clark in order to prevent affirmance by an equally divided court. ${ }^{13}$ Justice Black, with whom two justices ${ }^{14}$ and the Chief Justice concurred, favored the decision of the court of appeals, which would allow the plaintiffs to maintain their direct actions without regard to the limitation proceedings. Thus, three different solutions were advocated by the Supreme Court. ${ }^{15}$ Justice Frankfurter and three other justices felt that the conflict between state and federal law was so complete that the only solution was to refuse to give the state statute any effect. Justice Clark thought that the conflict could be reconciled simply by ordering the limitation proceeding to take place first,

${ }^{11}$ Cushing v. Texas \& P. Ry. Co., 99 F. Supp. 681 (E.D. La., 1951). More specifically, the district court refused to distinguish between hull insurance proceeds, which by The City of Norwich, 118 U.S. 468 (1886), cannot be reached by claimants, and proceeds of a protection and indemnity policy. See p. 557 infra.

12 Cushing v. Maryland Casualty Co., 198 F. 2d 536 (C.A. 5th, 1952).

${ }^{23}$ Joining Justice Frankfurter were Justices Reed, Jackson and Burton.

14 Justices Douglas and Minton.

${ }^{15}$ The precedent value of the decision is a difficult problem. The narrowest holding of a majority of the justices sitting is that the limitation proceeding should precede the direct actions against the insurer (Justices Clark, Frankfurter, Reed, Jackson and Burton). Five justices agreed, however, that direct actions could be brought, thus increasing the liability of the insurer beyond that of the insured shipowner (Justices Clark, Black, Douglas, Minton and Warren). In addition, five justices felt that the policy of the Limitation Act required that shipowners entitled to limitation under the Act be able to insure themselves against loss of the vessel by the purchase of insurance equal in amount to the value of the vessel (Justices Clark, Frankfurter, Reed, Jackson and Burton). Four justices flatly disagreed with each of these three propositions. Justice Clark, because he alone agreed to all three propositions, wrote the opinion for the Court. The precedent value of this case would appear to be limited to the first proposition, since that is the only one which describes the action actually taken in the case.

Undoubtedly the Court will have a second chance to pass on the question when the limitation proceeding has been concluded and the direct actions against the insurer are revived. The death of Justice Jackson has added a further unsettling factor: five justices now are on record as favoring the maintenance of direct actions in this situation with only three presently opposing it. 
while Justice Black and the remainder of the Court could see no state-federal conflict of any sort. ${ }^{16}$

\section{I}

Justice Black, in his dissenting opinion, argued that the concurrent state power to regulate marine insurance (so long as it does not interfere with the essential features of substantive maritime law) compels the conclusion that direct actions are permissible. The presence of such concurrent power may be admitted; ${ }^{17}$ the serious question is whether direct actions infringe upon federal maritime policy. Justice Black thought they do not:

It is said ... that other shipowners might have to pay higher premiums and also buy more insurance if recoveries are allowed here, and that this would discourage investment in ships. How the Limited Liability Act may be read to impose a ceiling on premiums, over which the states normally have full power, is difficult for me to understand. I have searched the Act's history in vain for any support for this interpretation. Yet 103 years after the Act's passage it is discovered that Congress intended to help shipowners by preventing states from making regulations that might raise the cost of marine insurance. But Congress decided to help shipowners by reducing their obligations due to wrecks, not by reducing the prices they had to pay for carrying on their business either before or after a wreck. Construing the Act to protect shipowners from having to pay higher prices for oil or coal would be no less farfetched than construing it to keep down insurance premiums. 18

The Limitation of Liability Act ${ }^{19}$ embodies a policy designed to encourage the American maritime industry. ${ }^{20}$ The Act, passed in 1851, limits the li-

${ }^{10}$ When the owner is entitled to limitation, three formulas for recovery may be derived from these three answers. Under the view of Justice Frankfurter insurance can never enlarge the amount of recovery by injured claimants; as has been the rule up to the present, the amount of recovery will vary from nothing to the value of the undamaged ship. Thus, in the present case the claimants would recover $\$ 25,000$. Under Justice Black's view the possible recovery would be increased over the Frankfurter view in every case by the amount of insurance; the total recovery would vary from an amount equal to the value of the undamaged ship to twice that amount, assuming protection and indemnity insurance to the full value of the ship. Plaintiffs could here recover $\$ 195,000$ : $\$ 170,000$ from the insurer and $\$ 25,000$ from the owner. Justice Clark would always permit recovery up to the amount of the insurance, irrespective of the damage to the ship. In the present situation the claimants would recover, under this view, $\$ 170,000$ : $\$ 25,000$ from the owner (who would then be indemnified for that loss by the insurer) and $\$ 145,000$ from the insurer, the balance of the face value of the insurance policy.

${ }^{17}$ U.S. Const. Art. $3, \S 2$, grants to the federal courts jurisdiction over admiralty and maritime cases. The Constitution does not mention legislative power over maritime matters.

${ }^{18}$ Maryland Casualty Co. v. Cushing, 347 U.S. 409, 435 (1954).

${ }^{19} 9$ Stat. 635 (1851), as amended, 46 U.S.C.A. $\$ \$ 183,186$ (1928).

${ }^{20}$ Cong. Globe, 31st Cong. 2d Sess. 331 col. 3, 713 col. 3 (1851). For legislative history of the Limitation Act consult Sprague, Limitation of Ship Owners' Liability, 12 N.Y.U. L. Q. Rev. 568 (1935), and Springer, Amendments to the Federal Law Limiting the Liability of Shipowners, 11 St. John's L. Rev. 14 (1937). The Act was passed to insure 
ability of owners to the value of the vessel involved unless the owner was personally negligent. It does not mention any right accorded to insurers. The direct actions, therefore, do not literally violate the federal statute: the liability of owners still cannot exceed the value of the vessel involved in the accident. Justice Black thought that this argument supports his conclusion that the Act should be read narrowly. But since the possibility of a direct action was not contemplated in 1851 , this argument is at best inconclusive. Since Congress could not have foreseen the present problem, it is indulging in literalism to argue that Congress, by the words chosen, unwittingly supplied a solution which may destroy the effect of its legislation.

Under Justice Black's solution, the shipping industry would eventually bear the cost of the increased recoveries of injured claimants in the form of higher premiums. ${ }^{21}$ The new premium rates would be set at a level high enough to shift this new burden entirely onto members of the shipping industry who purchase insurance. Since "substantially all marine risks are insured,"22 direct actions would eliminate virtually all the benefits conferred by the Limitation Act. Further, while the scant legislative history of the act does not mention insurance, ${ }^{23}$ marine insurance was commonplace in $1851 .{ }^{24} \mathrm{It}$ is probable, therefore, that Congress recognized the close relationship between insurance rates and the Limitation Act, and intended to preserve low insurance rates and extensive coverage for marine risks by passing the Limitation Act. ${ }^{25}$ Justice Black, ignoring these probabilities, would permit the state to remove indirectly the major benefits of the Limitation Act.

the continued ability of the American maritime industry to compete with other nations, most of whose merchant marines were operating under various systems of limited liability. Prior to the Act only Maine and Massachusetts had enacted statutes limiting the shipowner's liability [Me. Rev. Stat. (1840) c. 47, \$\$ 8-11; Mass. Rev. Stat. (1835) c. 32 , \$1-4]. Elsewhere in the United States there was no right to limitation.

${ }^{2}$ Under this view claimants could recover the entire proceeds of liability insurance policies (provided that they can show damage in that amount) irrespective of the fact that the owner's liability (and heretofore the insurer's) may be nothing, or an amount less than the face value of the policy.

${ }^{22}$ See Keen v. Overseas Tankship Corp., 194 F. 2d 515, 518 (C.A. 2d, 1952).

${ }^{2}$ Cong. Globe, 31st Cong. 2d Sess. 331 col. 3, 713 col. 3 (1851).

${ }^{24}$ While personal-injury and wrongful-death claims were at this time in their infancy, hull insurance and insurance to indemnify for liability for damage to cargo and other ships (to which the Limitation Act also applies) were well established. Consult Libby, Some Aspects of Protection and Indemnity Insurance, [1952] Ins. L. J. 684.

${ }^{25}$ Justice Frankfurter states: "That the cost and indeed the availability of insurance depends on limited liability was brought to the attention of Congress in the hearings on the 1936 amendments to the Limitation Act." 347 U.S. 409, 417 n. 6 (1954). It is doubtful that such subsequent legislative history conclusively determines the original intent. Consult 4 Hearings before House Committee on Merchant Marine and Fisheries on H.R. 9969, 74th Cong. 2d Sess. (1936) ; Hearings before House Committee on Merchant Marine and Fisheries on H.R. 4550, 74th Cong. 1st Sess. (1935). 


\section{II}

Justice Clark advocates a delay of the direct actions until after the limitation proceeding is concluded and indemnity given to the owner; direct actions would then be permitted if authorized by state law. ${ }^{26}$ Justice Clark feared that the shipowner may lose his "right" to be indemnified by his insurer for liabilities determined in a limitation proceeding if direct actions were permitted without regard to the limitation proceeding. Certainly his fear is well founded: if total claims in the direct action exceed the face value of the insurance, all funds otherwise available for the indemnification of the owner might be exhausted.

Justice Clark's opinion directly raises the question whether the owner has a federally created right to secure indemnity from his insurer for liabilities incurred in a limitation proceeding. Justice Frankfurter agreed that such a policy existed, but Justice Black was shocked at the suggestion:

I cannot believe ... [the owner] has an insurable "interest" in his seamen which could possibly entitle him to reduce the already limited financial obligations the Act imposes by taking for himself insurance money which otherwise would go to compensate seamen or their families for injuries he inflicts. . . 27

The arguments favoring Justice Clark's view appear plausible. The idea that there is a property risk which cannot be protected by insurance is rather startling: it appears to be tantamount to a holding that shipowners are a peculiar class who are not permitted to insure. ${ }^{28}$ Justice Frankfurter quotes the following statement of Justice Bradley with complete approval:

Now, to construe the law in such a manner as to prevent the merchant from contracting with an insurance company for indemnity against the loss of his investment is contrary to the spirit of commercial jurisprudence. ${ }^{20}$

\footnotetext{
${ }^{28}$ If the Clark view were to be permanently adopted by the Court, allowing direct actions provided they follow the limitation proceeding, premiums for protection and indemnity insurance probably would be substantially increased for vessels operating in Louisiana waters. Policies might be written with provisions making them void so long as a vessel is in Louisiana waters. E. G. Dicus, a Chicago insurance broker, felt that this would be a more likely result than an overall increase in premiums. If an overall increase in premiums did result, however, other states might be more inclined to enact statutes similar to that of Louisiana, since Louisiana claimants would then be benefiting from the increased premiums paid by shipowners elsewhere than in Louisiana. It is to be noted, however, that other states have not imitated Louisiana in permitting direct actions on policies written out of state.

Another possible effect of the Clark view is that the increased costs of operating in Louisiana might cause a gradual change of traffic patterns away from Louisiana ports and waterways. Louisiana's strategic geographical location for both inland and oceangoing traffic would minimize any such movement.

${ }^{2 \pi} 347$ U.S. 409, 435 (1954).

${ }^{23}$ This idea was summarized by Justice Frankfurter: "Without having bought any policies they could only have been held for $\$ 25,000$. If they buy the policies, and the Louisiana statute is applied to permit these suits, their liability is still $\$ 25,000 . " 347$ U.S. 409, 418-19 (1954).

2977 U.S. 409, 419 (1954), quoting from The City of Norwich, 118 U.S. 468, 504 (1886).
} 
Since the maritime industry has always relied on insurance to guard against heavy risks, these arguments appear forceful.

A comparison between the usual corporate liability and shipowner's liability under the Limitation Act illustrates the deceptiveness of the ClarkFrankfurter argument. For example, a corporation having assets of $\$ 25,000$ may purchase $\$ 170,000$ of liability insurance. But it does not thereby protect itself against the possible loss of its assets to personal-injury claimants. If a judgment for $\$ 195,000$ is entered against it, for example; the insurer would pay only to the face value of the policy, $\$ 170,000$. Since the judgment is still not fully satisfied, execution may be levied on the corporation's assets. In contrast, if no direct action is permitted against the insurer of the Jane Smith, the owner would be liable for only $\$ 25,000$ in a limitation proceeding irrespective of the size of claims. ${ }^{30}$ Such a loss would be completely covered by the $\$ 170,000$ insurance policy.

A succession of benefits has been granted to shipowners by Congress and the courts. First, the Limitation Act provided that the shipowner's liability cannot exceed the value of the vessel plus freight pending. Second, in Norwich Company v. Wright ${ }^{31}$ it was held that the shipowner's liability was limited to the value of the damaged vessel following an accident plus freight pending. Third, in The City of Norwich ${ }^{32}$ the proceeds of hull insurance were held not available to claimants, despite the uncertainty of legislative intent. ${ }^{33}$ The views of Justices Clark and Frankfurter in Maryland Casualty Co. v. Cushing would add a fourth benefit: shipowners who are entitled to limitation under the Act could insure themselves against loss of the vessel merely by purchasing insurance equal to its value. This fourth benefit would release shipowners entirely from the risks of a voyage.

\footnotetext{
${ }^{30}$ The owner would be unlimitedly liable and limitation would be denied if his negligence caused the accident. It is here assumed that there was a right to limitation of liability.

${ }^{21} 13$ Wall. (U.S.) 104 (1871). ${ }^{32} 118$ U.S. 468 (1886).

${ }^{33}$ Cong. Globe, 31st Cong. 2d Sess. 331 col. 3 (1851). The sponsor of the Act declared that it was "predicated on what is now the English law" (ibid., at 332 col. 1). Commencing with the first English statute which limited liability, the Act of 7 George II, c. 15 (1734), English shipowners were held liable to the value of the vessel and freight pending before the accident. When the vessel was surrendered in satisfaction of claims, insurance was surrendered with it. Since difficulty was often encountered in determining this value, the present English statute, the Merchant Shipping Act of $1894,57 \& 58$ Vict., c. $60, \S 502$, provided that a sum based on the ship's tonnage must be available for payment of claims. Such a scheme for sea-going vessels was adopted by Congress in 1936. 49 Stat. 960, 1479 (1936), 46 U.S.C.A. $\$ 183$ (b)-(e) (Supp., 1953). The continental countries, unlike England, limited the owner's liability to the value of the wreck. The statement of the sponsor of the American Act strongly suggests, however, that Congress intended to follow the English system.

While the dissenting opinion in The City of Norwich [118 U.S. 468, 526 (1886)] makes an appealing argument that hull insurance proceeds should be available to claimants, the vitality of this decision cannot be questioned. With the advent of dangerous industrial operations and the air age it would seem that the maritime industry is no longer unique, as it was until the middle of the nineteenth century, in its liability-incurring potential.
} 
Justices Clark and Frankfurter would give shipowners benefits considerably greater than those accorded corporations engaged in other activities. It is incorrect to argue that if the Black view be adopted shipowners would be placed in a position inferior to that of other entrepreneurs; an exact parallel with general corporate liability is maintained only by a solution which does not grant the owner indemnification if the claims involved exceed the value of the insurance. The question that must be resolved, then, is whether Congress by passing the Limitation Act intended to grant shipowners this additional benefit.

While no certain answer can be given, the more reasonable contention appears to be that Congress intended no such benefit. The apparent intent of Congress was that the risk involved in any one voyage was to be limited to the assets actually risked in the voyage. In this respect the Limitation Act is closely analogous to the corporation statutes, which exempt the personal funds and other assets of stockholders from seizure for the payment of claims arising from the corporation's business. Nowhere does it appear that Congress intended to eliminate all risk in the shipping industry; rather, the statute grants explicitly only a partial exemption of assets. The negative inference is that the other assets are not to receive increased protection.

If this analysis be correct, then Justice Clark's solution suffers from a double error. Not only would he grant the shipowners a benefit not contemplated by the Act, but also he would force them to pay indirectly liabilities exceeding those provided by the Act. Since he would permit a direct action against the insurer for the remainder of the insurance after the limitation proceeding, total recoveries by claimants would be increased, and the owners would eventually be forced to pay in the guise of increased premiums. In this respect Justice Clark's view involves the same difficulty as the solution suggested by the dissenting justices.

One possible advantage of this view is that the sum available to claimants is always readily determinable (total value of the protection and indemnity insurance). The value of the ship after the accident would be recoverable in the limitation proceeding, and, after the owner had been indemnified, the claimants could recover the remainder of the insurance.

\section{III}

Justice Frankfurter took the position that the conflict between the Louisiana direct action statute and the federal maritime policy could be resolved only by not permitting direct actions against insurers. He felt that direct actions would destroy the federal requirement of concursus of claims. The Rules of Admiralty assure all claimants an opportunity to obtain a pro rata share of available funds, ${ }^{34}$ and direct actions would endanger this policy. If, for example, more enterprising claimants exhaust the insurance by a direct

${ }^{84}$ Admiralty Rules 51-54, 28 U.S.C.A. (1950). 
action, and then it is determined in the limitation proceeding that the owner is not entitled to limitation, other claimants will not receive their pro rata share if the owner is insolvent. In this situation some claimants who rely on federal law (the Limitation Act and the Rules of Admiralty) are penalized. This argument apparently does not apply to situations in which the owner is entitled to limitation. ${ }^{35}$ The concursus only assures claimants a pro rata share of the owner's assets; even if the insurance had been exhausted, claimants could still receive their pro rata share directly from the sale of the damaged vessel..$^{36}$ Moreover, since Justice Clark would defer the direct action until the limitation proceeding is concluded, this criticism cannot be applied to his solution.

Justice Frankfurter also notes two other problems discussed above. $\mathrm{He}$ felt that the shipowners should not be deprived of the possibility of insuring completely against all risks, and was willing to enthrone such a policy as positive federal law. He further argued that the increase in the cost of insurance which would result from either the Black or Clark solution would undermine the policy of the Limitation Act.

By advocating a strict maintenance of the status quo, Justice Frankfurter successfully avoids a solution which indirectly increases the liability of the shipping industry beyond that provided by the Limitation Act. A refusal to give effect to a state law is, however, a drastic step which should not be taken unless a failure to do so would infringe upon federal maritime policy. The conflict which Justice Frankfurter finds is not on its face irresolvable, and therefore he may have been hasty in refusing to give effect to the Louisiana statute. While, of the three solutions advocated by the Supreme Court, his is probably the most reasonable, it should not be accepted until all attempts have failed to find a solution which avoids serious federal-state controversy and which also gives effect to state law insofar as possible.

IV

A solution which avoids conflict with the federal maritime policy must restrict the owner's liability to the limits provided by the Limitation of

${ }^{\mathrm{x}}$ In a case where limitation of liability was denied in the admiralty proceeding, judgment against the shipowner could be rendered without regard to the value of the ship. Hence there would be no direct action against the insurer, since the claim has been reduced to judgment against the insured shipowner.

${ }^{36}$ Justice Frankfurter's argument of the necessity of preserving the concursus requirement appears to threaten substantive rights of recovery only in a minority of situations, contrary to the implication in the text of his opinion. Justice Frankfurter also suggests that direct actions would remove the benefits owners receive from concursus. Owners, their employees, and other witnesses of the accident need appear only once, and all claims are settled; now, direct actions might be instituted in twenty states, and the "crew [may be kept] off of the ship traveling around the country for 2 or 3 years." 347 U.S. 409, 415-16 (1954) [quoting a statement by Charles S. Haight, representing the French Line, 4 Hearings before the House Committee on Merchant Marine and Fisheries on H.R. 9969, 74th Cong. 2d Sess. 70 (1936)]. 
Liability $\mathrm{Act}^{37}$ and maintain the liability of the insurer at its present level in order to prevent a rise in insurance rates, ${ }^{38}$ but need not assure indemnification to the owner for liabilities imposed in the limitation proceeding. ${ }^{39}$

A solution consistent with these propositions may be derived from the parallel between the owner's liability under the Limitation Act and the liability of a corporation. ${ }^{40}$ Under the Limitation Act, the owner risks only his ship; his other assets cannot be seized by claimants. Similarly, the personal assets of shareholders in a corporation cannot be taken to satisfy claims against the corporation; the only assets risked are those owned by the corporation. But, even though the corporation may purchase insurance, it cannot protect its assets from injured claimants if their claims exceed the liability of the corporation's insurer. A similar solution applied to the maritime situation would resolve the present conflict. If premiums are not to be raised, the insurer's liability cannot exceed what it is at present-an amount equivalent to the liability imposed on the owner in the limitation proceeding. Therefore the claimants in the Cushing case could recover $\$ 25,000$ from the insurer in direct action and $\$ 25,000$ from the owner in a limitation proceeding. Since the insurer's liability has been exhausted, the owner could not recoup his loss from the insurer. ${ }^{41}$ The liability of the insurer has not been increased, and consequently, the cost and availability of insurance have not been affected. Moreover, the owner, in accordance with the terms of the Limitation Act, now risks no more than the value of the ship in its then condition. Finally, the Louisiana statute is given its maximum effect consonant with federal law, the insurance being made available for the protection of the injured. ${ }^{42}$

Altering the facts slightly, if claims in the Cushing case were to total $\$ 40,000$, a parallel with the corporate situation would require the insurer to pay $\$ 25,000$ and the owner $\$ 15,000$ with no indemnification. If the claims were $\$ 20,000$, the insurer would pay the total recovery. In general, the insurer's liability is first exhausted, and only then may assets be taken from the owner. If, on the other hand, the ship were completely destroyed, there could be no recovery; if the ship were fully insured and undamaged, claimants

\footnotetext{
${ }^{37}$ See page 551 supra.

${ }^{30}$ See page 556 supra.

${ }^{38}$ See page 555 supra.

${ }^{40}$ See page 557 supra.
}

"In practice, the plaintiffs might simultaneously levy execution on the vessel and bring an action against the insurer, when it is apparent that the insurer's liability on the policy will not entirely satisfy the total amount recoverable by them.

"2 Justice Black states: "Acting consistently with this broad trend in the law, Louisiana has tried to make certain that all liability insurance will get to those for whose protection it was purchased." 347 U.S. 409, 438 (1954). That Louisana looks upon liability insurance as a protection for the public as well as for the financial protection of the insured is indicated in Davies v. Consolidated Underwriters, 199 La. 459, 6 So. $2 \mathrm{~d}$ 351 (1942), and West v. Monroe Bakery, 217 La. 189, 210, 46 So. 2d 122, 131 (1950). 
could conceivably recover twice the value of the ship..3

Practically, the limitation proceeding should precede the direct action, for only there can the owner's liability (and also the insurer's) be determined.4 The direct action will then determine whether the total judgments will exceed the judgment rendered in the limitation proceeding. Finally, an action between the owner and insurer may be necessary to apportion the losses as indicated above.

Several things should be noted about this proposed solution. In the first place it may seem strange that low insurance rates are protected and yet the owner is no longer assured of indemnification. Yet this is the case since the liability of the insurer, which is the factor determinative of insurance rates, is unaffected.

Secondly, though the liability of the insurer was limited to the then value of the ship because of a federal policy (to prevent an additional liability from being passed on to the shipping industry), it appears that it may also be justified by the explicit terms of the contract of insurance. Policies usually contain a clause which states that the "liability of the insurer shall not exceed that of the insured in the absence of contract." While Louisiana has acted to remove clauses prohibiting direct actions against the insurer, ${ }^{45}$ it has not removed the "shall not exceed" clause. After the "no direct action" clause has been removed, ${ }^{46}$ this clause usually has no meaning; such is not the case in the maritime situation. The liability of the shipowner has been qualified by the Limitation Act, but the potential liability of the insurer in a direct action is not subject to limitation. ${ }^{47}$ Since there is no reason why

${ }^{2}$ This solution differs from that of Justice Clark in that Clark would permit the shipowner to be indemnified in every case, and would hold the insurer for the full amount of the policy in every case where claimants show damage in that amount. Justice Black would in all cases permit claimants to recover the face value of the insurance policy and the value of the ship after the accident. Justice Frankfurter would never permit insurance to enlarge a recovery; it would always be a sum equal to the value of the ship after the accident. Thus, the suggested solution, with recoveries varying from nothing to twice the value of the ship, embraces the monetary gamut of all the solutions proposed by the Court, assuming that protection and indemnity insurance to the value of the vessel is purchased.

"This would, of course, meet Justice Frankfurter's argument that direct actions destroy the benefits of a concursils of claims. See page 558 supra.

« 15 La. Stat. Ann. (West, 1951) $\$ 22: 655$.

${ }^{46}$ The "shall not exceed" clause implies that the insured's liability should be first determined so that the insurer may be certain that it is not paying an excessive sum to an injured claimant. The Louisiana statute, however, explicitly permits a direct action against the insurer. See note 10 supra. It should be noted, however, that the possible liability of both the insurer and the insured is unlimited, so that the statute may be viewed as effecting a simple change of parties without increasing the insurer's liability beyond that of the insured.

${ }^{17}$ The maritime situation differs from the usual situation in that the owner may be entitled to limitation. If the action against the insurer proceeds to judgment before the limitation proceedings are completed, the judgment against the insurer may be larger than the judgment to be rendered against the insured owner. 
this clause is invalid, the liability of the insurer shall not exceed that of the insured in the limitation proceeding. A state probably could not remove such a clause legitimately, since such an action would, in a manner similar to Justice Black's solution, interfere with the federal maritime law. It is curious that none of the opinions considered the applicability of this clause. ${ }^{48}$

Thirdly, it may be thought that under the proposed solution shipowners would no longer purchase liability insurance, since they still may lose the value of the damaged ship irrespective of the amount of insurance purchased. This deceptively convincing assertion may be answered as it is in the case of the corporation: the owner will insure to protect himself from losses resulting from small claims. For example, if he is insured, the owner will lose nothing if the claims are less than the value of the damaged ship. If the claims exceed the value of the ship, he will lose only the difference between the claims and the value, but never more than the value of the ship. But, it may then be objected, the owner is unlike the corporation in that a purchase of more insurance will protect the corporate assets against larger claims, but the amount of insurance purchased by shipowners does not affect the probability of his losing his ship. That danger is determined solely by the value of the damaged ship and the size of the damage claims. The disadvantage to the shipowner inherent in the fact that he may lose his vessel no matter how much insurance he has purchased may be more than offset by the advantage of lower insurance rates.

Despite this disadvantage, owners probably will still protect themselves through insurance. Since the damage to the ship is an unpredictable factor, the owner will purchase an amount of insurance equal to the full value of the vessel in order to guard against situations involving heavy claims but no damage to the vessel. Further, there is always a possibility that the owner will not be entitled to limitation; in that situation the analogy with the corporation is complete. To guard against this possibility, the owner may still desire to purchase insurance in excess of the value of the vessel.

The Louisiana direct action statute embodies a policy designed to protect the injured by making insurance immediately available to them. Federal law, as expressed in the Limitation of Liability Act, states in effect that it is willing that the shipowner lose the ship risked with each voyage but not his other assets, and increased insurance rates deplete these assets indirectly. The proposed solution would extend to the injured the benefits of state law by permitting direct actions to increase the owner's loss to the maximum extent consistent with federal law. Both federal and state policies would be given effect and paramount federal interests would not be impaired.

\footnotetext{
${ }^{28}$ It seems likely that counsel may not have put the clause in issue. Naturally it would not be alluded to by counsel for the plaintiff; defense counsel may have chosen not to bring it in issue on the hope that the Frankfurter opinion would prevail, in which case the clause would become a moot question.
} 